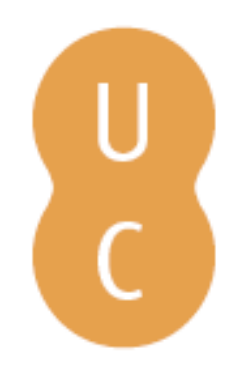

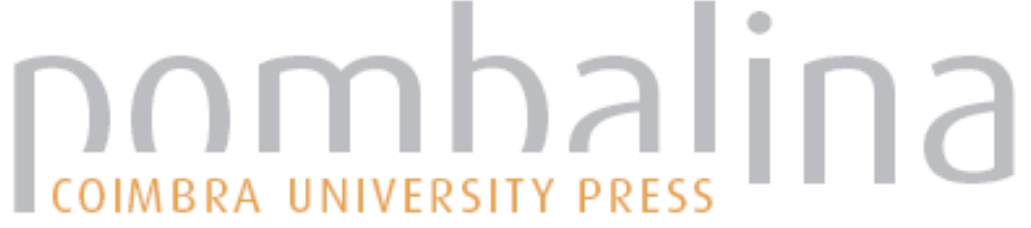

\section{One of the finest literary minds of her generation}

\author{
Autor(es): Bercovitch, Sacvan \\ Publicado por: Imprensa da Universidade de Coimbra \\ URL \\ persistente: URI:http://hdl.handle.net/10316.2/42360 \\ DOI: $\quad$ DOI:https://doi.org./10.14195/978-989-26-1308-6_46
}

Accessed : $\quad$ 26-Apr-2023 16:00:52

A navegação consulta e descarregamento dos títulos inseridos nas Bibliotecas Digitais UC Digitalis, UC Pombalina e UC Impactum, pressupõem a aceitação plena e sem reservas dos Termos e Condições de Uso destas Bibliotecas Digitais, disponíveis em https://digitalis.uc.pt/pt-pt/termos.

Conforme exposto nos referidos Termos e Condições de Uso, o descarregamento de títulos de acesso restrito requer uma licença válida de autorização devendo o utilizador aceder ao(s) documento(s) a partir de um endereço de IP da instituição detentora da supramencionada licença.

Ao utilizador é apenas permitido o descarregamento para uso pessoal, pelo que o emprego do(s) título(s) descarregado(s) para outro fim, designadamente comercial, carece de autorização do respetivo autor ou editor da obra.

Na medida em que todas as obras da UC Digitalis se encontram protegidas pelo Código do Direito de Autor e Direitos Conexos e demais legislação aplicável, toda a cópia, parcial ou total, deste documento, nos casos em que é legalmente admitida, deverá conter ou fazer-se acompanhar por este aviso.

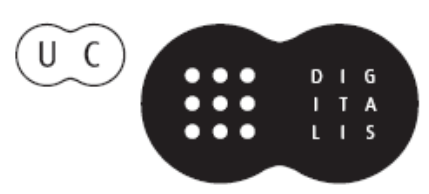





\section{ONE OF THE FINEST LITERARY MINDS O F H E R G E N E R A T I O N}

Sacvan Bercovitch, 19.11.2014

One of the finest literary minds of her generation. A major Americanist and literary-cultural scholar. No one in our time has done more to broaden and deepen European-American Studies. A unique, and uniquely wonderful, human being. 